\title{
Digestive System Complication
}

National Cancer Institute

\section{Source}

National Cancer Institute. Digestive System Complication. NCI Thesaurus. Code

C115214.

Any disorder of the organs of the digestive system occurring as a consequence of injury to the digestive system. 